\title{
Meningkatkan Prestasi Belajar Siswa Kelas XII IPS 1 Dengan Metode Pemberian Tugas Di Sekolah Menengah Atas Negeri 1 Muaro Jambi
}

\author{
Elizawati \\ Sekolah Menengah Atas Negeri 1 Muaro Jambi, Indonesia \\ E-mail: eliza23@gmail.com
}

\begin{abstract}
The purposes of this study are to get bolstering about the students' learning achievement in returning the paper task, to improve students' skill in doing theirs task, to increase responsibility of students, to raise students interest, and to reach students' achievement in Geography learning in XII IPS 1 SMA Negeri 1 Muaro Jambi. The data collected through observation, documentation and interview. Furthermore, the subjects of this study consisted of 27 students XII IPS 1 SMAN 1 Muaro Jambi. This study run from July to September 2014. The result of study displays that the paper task retirning method can improve students' achievement. The sign of improvement is shown by improving students's rate in geography learning that starts from cycle 1 to cycle II. Another result is this method can develop students' interest in learning.
\end{abstract}

Keywords: students' learning achievement, paper task, returning paper's task

\section{Pendahuluan}

Pendidikan adalah suatu proses belajar mengajar yang pada akhirnya dapat menghasilkan perubahan tingkah laku yang diharapkan. di Indonesia sejak berlakunya UU no. 20 tahun 2003 tentang pendidikan nasional, maka jenis upaya pendidikan perlu disesuaikan dengan UU tersebut. Dalam era globalisasi pada saat ini keprofesionalan seorang guru dalam bidangnya dituntut secara optimal disamping kurikulum yang berkualitas terwujudnya tujuan pembelajaran. Guru sebagai salah satu komponen sangat menentukn keberhasilan proses pendidikan, karena mereka terlibat langsung.

Hal ini dapat diteliti melalui tugas dan peranan guru sebagai komunikator,fasilitator, motivator dalam proses belajar mengajar menekankan bahwa oleh karena belajar adalah menyangkut apa yang diharuskan dan dikerjakan murid-murid untuk menjadi dirinya sendiri, maka inisiatif harus datang dari murid-murid itu sendiri.

Guru adalah pembimbing, pengarah yang mengemudikan perahu, tetapi tenaga untuk menggerakkan perahu tersebut haruslah berasal dari mereka atau murid yang belaja, jadi para murid harus didorong dan dirangsang untuk belajar bagi diri mereka sendiri,dan tugas guru yang sebenarnya adalah menjamin bahwa murid-murid menerima tanggung jawab sendiri untuk belajar dengan mengembangkan sikap. Bersamaan dengan tugas dan peranan guru dan kegiatan 
pembelajaran diharapkan menyadari bahwa proses pembelajaran memerlukan persiapan administratif maupun persiapan bahan pelajaran. Proses pembelajaran memerlukan keterampilan guru dalam mengelola kelas.

Guru diharapkan dapat menyampaikan bahwa pembelajaran dengan menggunakan pendekatan pembelajaran tertentu yang melihat sebanyak mungkin kemampuan peserta didik selama berlangsung proses pembelajaran dengan memilih metode pembelajaran yang tepat.

Sesuai dengan tujuannya mengingat metode pemberian tugas merupakan suatu cara penyajian bahan keilmuan dengan menugaskan para peserta didik yang sering diistilahkan dengan pekerjaan rumah (PR), dengan mengerjakan tugas maka peserta didik akan tumbuh dan berkembang kreatifitasnya disamping bertambah wawasan dan keterampilan. dalam mencapai tujuan tersebut sistem belajar mangajar di SMA Negeri 1 Muaro Jambi, terutama di kelas XII IPS 1 pada mata pelajaran geografi menerapkan pendekatan pembelajaran dengan menggunakan metode pemberian tugas yang lembar kertas tugas jarang atau kadang-kadang tidak dikembalikan kepada siswa.

Menurut pengamatan sementara kecendrungan guru dalam memeriksa, memberi penilaian serta mengembalikan kertas tugas siswa sangat rendah. Hal ini disebabkan oleh banyaknya kendala seperti yang disebutkan diatas, disamping juga karena tersitanya waktu guru untuk kegiatan yang lainnya di antaranya jam mengajar yang terlalu banyak dan lain-lain, sehingga tercipta situasi belajar tanpa PR. Hal ini sangat merugikan siswa dan dangkalnya wawasan keilmuan para anak didik. Guru haruslah mengupayakan keaktifan siswa dengan menetapkan metode pemberian tugas, serta kertas tugas siswa harus di kembalikan agar menjadi umpan balik bagi siswa, sehingga tercipta proses belajar yang efektif dan efisien.

Dalam penelitian ini yang menjadi fokus persoalan adalah bagaimana motivasi pelajaran apabila di kaitkan dengan usaha pengembalian kertas tugas, maka siswa akan mengetahui tentang hasil belajar yang dicapainya. Jika seorang siswa mendapat nilai sesuai dengan yang diharapkan, maka siswa tersebut besar kemungkinan untuk berusaha mempertahankan atau meningkatkan hasil belajarnya dengan strategi yang digunakan. Sebaliknya, jika seorang siawa mendapat nilai yang tidak sesuai dengan harapannya, maka siswa tersebut mungkin akan menggunakan strategi belajarnya untuk masa yang akan datang.

Untuk mendapatkan ketegasan, bahwa metode pemberian tugas akan dapat meningkatkan prestasi belajar dan dapat meningkatkan motivasi dan intensitas belajar, sehingga meningkatkan terhadap hasil belajar siswa, maka perlu dikaji melalui suatu penelitian.

Penelitian ini bertujuan untuk mendapatkan ketegasan tentang ada atau tidak adanya perbedaan prestasi belajar siswa dengan pengembalian kertas tugas. Disamping itu juga bertujuan untuk dapat:

1. Meningkatkan keterampilan siswa kelas XII IPS 1 mengerjakan apa yang ditugaskan;

2. Meningkatkan tanggung jawab pada diri siswa dan memacu mereka untuk bersaing meningkatkan prestasi belajar; 
3. Meningkatkan minat siswa untuk belajar lebih giat lagi dari pada hari-hari sebelumnya;

4. Meningkatkan prestasi belajar Geografi siswa kelas XII IPS 1 SMA Negeri 1 Muaro Jambi dengan pengembalian kertas tugas.

\section{Belajar}

Para ahli banyak mendefiniskan tentang belajar, diantaranya Rusyan menyatakan sebagai berikut: (Tabrani Rusyan, 1989, p.7)

a. Belajar adalah memodifikasi atau memperteguh kelakuan melalui pengalaman

b. Belajar adalah suatu proses perubahan tingkah laku individu melalui interaksi dengan lingkungan

c. Belajar dalam arti luas ialah perubahan tingkah laku yang dinyatakan dalam bentuk penguasaan, penggunaan, dan penilaian terhadap atau mengenai sikap dan nilai-nilai, pengetahuan dan kecakapan dasar yang terdapat dalam berbagai aspek kehidupan atau pengalaman yang terorganisasi.

Sementara Purwanto mengartikan bahwa belajar mempunyai ciri-ciri sebagai berikut: (Nagalim Purwanto, 1991, p.85)

a. Belajar merupakan suatu perubahan dalam tingkah laku, yang perubahan itu dapat mengarah kepada tingkah laku yang lebih baik, tetapi juga ada kemungkinan mengarah kepada tingkah laku yang lebih buruk.

b. Belajar merupakan suatu perubahan yang terjadi melalui latihan atau pengalaman.

Untuk dapat disebut balajar, maka perubahan itu harus relative mantap. Tingkah laku yang mangalami perubahan karena balajar menyangkut barbagai aspek kepribadian baik fisik maupun psikis seperti perubahan dalam pengertian, pemecahan sesuatu masalah atau berfikir, ketrampilan, kecakapan, kebiasan ataupun sikap.

Selanjutnya belajar menurut Winkel belajar adalah sesutu aktifitas mental/psikis, yang berlangsung dalam interaksi aktif dengan lingkungan, yang menghasilkan perubahan-perubahan dalam pengetahuan-pemahaman, keterampilan dan nilai sikap, perubahan itu bersifat secara relatif konstan dan berbekas. (Winkel.W.S, 1991, p.36) Sejalan dengan Winkel, Gagne, dalam Purwanto menyatakan bahwa belajar terjadi apabila suatu situasi stimulus bersama dengan isi ingatan mempengaruhi siswa sedemikian rupa, sehingga perbuatannya berubah dari waktu sebelum ia mengalmi situasi itu ke waktu sesudah ia mengalami situasi tadi. (Nagalim Purwanto, 1991, p.85)

Menurut pandangan behaviorrristik, J.B. Watson, E.L. Thorndrike, dan B.F. Skinner dalam Dimyati, belajar adalah perubahan dalm tingkah laku, sedangkan menurut pandangan kognitif (Jean Piaget, Robert Glaser, John Anderson, Jerome Brunner dan David Ausubel), belajar adalah proses internal yang tidak dapat diamati secara langsung, perubahan terjadi dalam kemampuan seseorang untuk bertingkah laku dan berbuat dalam situasi tertentu, perubahan dalam tingkah laku hanyalah suatu refleksi dari perubahan internal. ( Mahmud Dimyati, 1989, p.122)

Selanjutnya Witherington dalam bukunya Educational Psychology yang dikutip Purwanto mengemukakan, bahwa belajar adalah sebagai sutu perubahan 
dalam kepribadian sebagaimana yang dimanifestasikan dalam perubahan peguasaan pola-pola respon atau tingkah laku yang baru, yang ternyata dalam perubahan keterampilan, kebiasaan, kesanggupan atau pemahaman. (Nagalim Purwanto, 1991, p.84)

Dari defenisi-definisi yang telah dikemukakan oleh para ahli di atas dapat dipahami bahwa belajar adalah suatu perubahan yang terjadi dalam diri seseorang, mengakibatkan timbulnya pengetahuan, kemampuan, dan tingkah laku yang baru dan dari tidak tahu menjadi tahu.

Dari berbagai sudut pandang dan pendapat para ahli di atas tentang pengertian belajar, maka dapat disimpulkan bahwa:

1. Belajar merupakan suatu aktifitas yang menyebabkan suatu perubahan pada diri individu yang belajar.

2. Perubahan-perubahan itu mengakibatkan timbulnya pengetahuan, kemampuan, dan tingkah laku yang baru.

3. Perubahan-perubahan tersebut terjadi karena usaha menerima menyeleksi suatu kepribadian yang didasarkan pada pengalaman.

4. Belajar merupakan usaha kearah kemajuan baik dalam bentuk penyesuaian diri maupun dalam bentuk lain yang lebih maju.

Dari rumusan di atas, maka dapat dikatakan bahwa kegiatan belajar membawa manusia kepada suatu perubahan. perubahan tersebut dapat berupa atau berbentuk pengetahuan, keterampilan, dan sikap serta kepribadian yang dimiliki oleh seseorang. jika dikaitkan dengan perolehan belajar, maka perubahanperubahan tersebut merupakan suatu indikasi untuk meningkatkan perolehan belajar. untuk mengetahui perolehan tersebut, maka dibutuhkan suatu evaluasi untuk mengukur tingkat perolehan belajar yang diperolehnya.

\section{Tujuan Belajar}

Dalam usaha pencapaian tujuan belajar perlu diciptakan adanya system lingkungan (kondisi) belajar yang lebih kondusif, hal ini akan berkaitan dengan mengajar. Di atas telah diuraikan, bahwa dengan belajar manusia dapat mewujudkan harapan dan cita-cita dalam hidupnya. Oleh sebab itu dalam melakukan aktifitas belajar sudah barang tentu mempunyai tujuan yang diharapkan.

Menurut Sardiman pada intinya tujuan belajara itu adalah ingin mendapatkan pengetahuan, keterampilan dan penanaman sikap mental/nilai-nilai. Releva dengan uraian mengenai tujuan belajar tersebut, maka hasil belajar itu meliputi : a) Hal ihwal keilmuan dan pengetahuan, konsep atau fakta(kognitif), b) Hal ihwal personal, kepribadianatau sikap(efektif), c) Hal ihwal kelakuan, keterampilan atau penampilan ( psikomotorik). (Sardiman, 1994, p.30)

Dengan memahami tujuan belajar tersebut di atas, maka seseorang yang belajar akan lebih mendapatkan hasil belajar yang baik. Oleh sebab itu perolehan belajar yang di dapat jug sedikit banyak turut ditentukan oleh pemahaman seseorang yang belajar akan tujuan belajarnya.Dengan demikian siswa dalam hal ini diharapkan memahami tujun belajar yang akan dicapai dari setiap proses belajar pembelajaran 


\section{Motivasi Belajar}

Banyak sekali,bahkan sudah umum orang menyebut motif "kata motif", diartikan sebagai daya upaya yang mendorong seseorang untuk melakukan sesuatu motif merupakan daya penggerak yag telah menjadi aktif. Menurut MC. Donald dalam Sardiman, motivasi adalah perubahan energi dalam diri seseorang yang ditandai dengan munculnya "Feeling" dan didahului dengan tanggapan terhadap adanya tujuan. (Sardiman, 1994, p.73)

Sedangkan menurut Winkel bahwa, motivasi belajar adalah keseluruhan daya penggerak psikis di dalam diri siswa yang menimbulkan kegiatan belajar, menjamin kelangsungan kegiatan belajar dan memberikan arah pada kegiatan belajar itu demi mencapai suatu tujuan. (Winkel.W.S, 1991, p.92)

Dari pengertian di atas dapat dipahami bahwa motivasi merupakan daya penggerak yang ada di dalam diri seseorang untuk melakukan aktivitas-aktivitas tertentu demi tercapainya suatu tujuan. Jadi motivasi bukanlah sesuatu yang dapat diamati, tetapi hasilnya yang dapat disimpulkan setiap kegiatan dan kejadian yang dilakukan oleh seseorang didorong oleh sesuatu kekuatan dalam diri orang tersebut, kekuatan pendorong itulah yang dinamakan dengan motivasi.

Bila dihubungkan dengan tujuan belajar maka motivasi merupakan alat pemacu atau pendorong bagi siswa untuk melakukan sesuatu perbuatan, yaitu perbuatan untuk belajar, hal ini dapat dilihat pada pengembalian kertas tugas pada umumnya dan kemampuan pribadi pada umumnya. Jenis atau golongan motivasi menurut Sardiman motivasi belajar terdiri dari motivasi intrinsik dan motivasi ekstrinsik. (Sardiman, 1994, p.88-90) Motivasi intrinsik adalah motif-motif yang menjadi aktif atau berfungsinya tidak perlu dirangsang dari luar, karena dalam diri setiap individu sudah ada dorongan untuk melakukan sesuatu, sedangkan motivasi ekstrinsik adalah motif-motif yang aktif dan berfungsinya karena adanya perangsang dari luar.

Dari kedua jenis motivasi belajar diatas jelas akan berhubungan langsung terhadap peningkatan hasil belajar yang diterima oleh siswa.

\section{Fungsi Motivasi Dalam Belajar}

Dalam kegiatan belajar sangat diperlukan adanya motivasi, karena dengan motivasi dapat menjadi pendorong untuk melakukan kegiatan belajar, sehingga tercapai hasil belajar yang optimal. Sardiman mengemukakan tiga fungsi motivasi: (Sardiman, 1994, p.85)

1. Mendorong manusia untuk berbut, yakni sebagai penggerak atau motor yang melepaskan energi. Motivasi dalam hal ini merupakan motor penggerak dari setiap kegiatan yang akan dekerjakan.

2. Menentukan arah perbuatan, yakni kea rah tjuan yang hendak dicapai. Dengan demikian motivasi dapat memberikn arah dan kegiatan yang harus dikerjakan sesuai dengan rumusan tujuan.

3. Menyeleksi perbuatan, yakni menentukan perbuata-perbuatan apa yang harus dikerjakan yang serasi guna mencapai tujuan, dengan menyisihkan perbuatan-perbuatan yang tidak bermanfaat bagi tujuan tersebut.

Disamping itu, ada juga fungsi-fungsi lain. Motivasi dapat berfungsi sebagai pendorong usaha dan pencapaian prestasi. Seseorang melakukan suatu usaha karena adanya motivasi. Adanya motivasi yang baik dalam belajar akan 
menunjukkan hasil yang baik. Dengan kata lain bahwa dengan adanya usaha yang tekun dan terutama didasari adanya motivasi, maka seseorang pelajar itu akan dapat melahirkan prestasi yang baik. Intensitas motivasi seseorang siswa akan sangat menentukan tingkat pencapaian prestasi belajarnya.

\section{Tujuan Motivasi dalam Belajar}

Sebagaimana yang disebut diatas, dan dikatakan bahwa motivasi merupakan suatu alat untuk mencapai tujuan. Begitu pula dengan maksud seseorang mengapa individu termotivasi disebabkan ingin mencapai tujuan. Bila seseorang termotivasi berarti adanya tujuan dari motivasi yang dilakukannya tersebut, sedang menurut Purwanto tujuan motivasi secara umum dapat dikatakan bahwa tujuan motivasi adalah untuk menggerakkan atau menggugah seseorang agar timbul keinginan dan kemauannya untuk melakukan sesuatu sehingga dapat memperoleh hasil atau mencapai tujuan tertentu. (Nagalim Purwanto, 1991, p.73)

Bagi seorang guru, tujuan motivasi dalah untuk menggerakkan atau memacu para siswanya, agar timbul keinginan dan kemauannya untuk meningkatkan prestasi belajarnya., sehingga tercapai tujuan pendidikan sesuai dengan yang diharapkan dan datetapkan didalam kurikulum sekolah.

Dari keterangan diatas, jelas bahwa setiap tindakan motivasi mempunyai tujuan. Makin jelas tujuan yang diharapkan atau akan di capai, makin jelas pula begaimana tindakan memotivasi yang dilakukan. Tindkan memotivasi akan lebih dapat berhasil jika tujuannya jelas dan didasari oleh yang dimotivasi serta sesuai dengan kebutuhan orang yang dimotivasi. Oleh karena itu, setiap orang yang akan memberikan motivasi harus mengenali dan memahami benar-benar latar belakang kehidupan, kebutuhan dan kepribadian orang yang akan di motivasi.

\section{Fungsi Kertas Tugas}

Lembar tugas bukan merupakan alat evaluasi tetapi sarana atau alat mengecek tingkat pemahaman peserta didik terhadap bahan/materi yang telah disajikan dan dipergunkan dalam proses belajar mengajar. Fungsi kertas tugas adalah berisi serangkaian pertanyaan yang harus dijawab atau permasahan yang harus deselesaikan,pengamatan yang harus dilakukan, bahan acuan yang harus dikonsultasikan, maupun berisi petunjuk untuk menyelesikan tugas. (Adipurnomo, Haryono, 1994, p.21)

Jenis tugas yang dapat diberikan kepada peserta didik, antara lain:

1. Tugas latihan

Tugas untuk melatih peserta didik menyelesaikan permasalahan yang berkaitan dengan bahan keilmuan yang telah disajikan. Dalam pelaksanaannya perlu disesuaikan dengan kebutuhan dan waktu.

2. Tugas membaca /mempelajari Buku Referensi

Peserta didik ditugaskan untuk membaca buku referensi pada halaman atau bab tertentu yang berkaitan dengan bahan keilmuan yang telah atau akan disajikan.

3. Tugas mempelajari suatu topik atau Pokok Bahasan

Tugas ini diberikan untuk mendorong peserta didik untuk mencari dan mempelajari sumber yang berkaitan dengan topik/pokok bahasan yang telah ditugaskan. 
4. Tugas unit/proyek

Tugas ini diberikan agar peserta didik dapat menghasilkan suatu karya. Dalam pelaksanaannya akan melibatkan kemampuan peserta didik dalam berbagai mata pelajaran.

Dalam penelitian ini jenis tugas yang dilaksanakan adalah latihan. Langkahlangkah yang dilaksanakan adalah :

1. Pemberian materi

2. Pemberian tugas

3. Koreksi tugas

Syarat-syarat yang perlu diperhatikan dalam memberikan tugas kepada peserta didik, antara lain:

1. Jelas dan Tegas

Untuk menghindari kekaburan peserta didik dalam memahami tugas dan banyak memakan waktu, maka perlu adanya kejelasan dan ketegasan tentang tugas, seperti, tugas diberikan secara tertulis di papan tulis atau lembar kerja yang berisikan apa yang harus dikerjakan, bagaimana mengerjakannya, siapa yang mengerjakannya, kapan tugas harus diselesaikan dan kalau mungkin diberikan daftar pertanyaan atau petunjuk yang dapat membimbing peserta didik dalam mengerjakan tugas.

2. Penjelasan Tentang Kesulitan yang Mungkin Dihadapi

Sebelum tugas dikerjakan, guru perlu menjelaskan kesulitan yang mungkin dihadapi peserta didik dalam mengerjakan tugas, misalnya, istilah baru yang terdapat dalam bahan tugas dan cara mengatasi kesulitan. Karena tugas yang tidak dapat dikerjakan akan membuat mereka frustrasi dan membenci pelajaran.

3. Membicarakan Tugas dengan Peserta Didik

Sebelum menugaskan peserta didik, guru perlu membicarakan bahan tugas dengan mereka, sehingga tugas sesuai dengan tingkat kemampuan dan minatnya. Disamping itu peserta didik tidak menganggap bahwa tugas yang diberikan sebagai beban yang memberatkan.

4. Kebermaknaan Tugas bagi Peserta Didik

Guna menyadarkan peserta didik akan tugas, maka guru perlu menjelaskan makna tugas yang harus diselesaikan demi kepentingannya. Jangan sebaliknya memberikan tugas sekaligus sanksinya, misalnya angka dikurangi. Maksud dan tujuan sebagaimana disebutkan diatas akan diwujudkan dengan memanfaatkan kelebihan dalam menerapkan metode ini untuk:

1. Melatih peserta didik melaksanakan serangkaian kegiatan agar menemukan pengalaman belajarnya dan selanjutnya akan mendorong tumbuhnya sikap tekun teliti dan kreatif

2. Mendorong perkembangan sikap dan kemampuan peserta didik dalam memikirkan dan melakukan sesuatu sekalipun sulit tanpa bantuan dan campur tangan dari pihak lain.

3. Mendorong peserta didik menilai diri sendiri seberapa jauh kelebihan dan kekurangan 
kemampuannya dalam mengerjakan tugas.

Prosedur secara umum dalam menerapkan metode pemberian tugas adalah sebagai berikut:

A. Tahap Persiapan

1) Menetapkan tujuan Pembelajaran yang hendak dicapai dengan pemberian tugas (penugasan)

2) Menetapkan topik, utamakan topik-topik dari pokok bahasan/sub pokok bahasan yang diperkirakan dapat dipelajari sendiri oleh peserta didik tanpa melalui bimbingan guru pada jam tatap muka.

3) Menetapkan prosedur kegiatan yang dilakukan oleh peserta didik dalam menyelesaikan tugas.

4) Menetapkan lamanya waktu untuk menyelesaikan tugas.

B. Tahap Pelaksanaan

1)Mengimformasikan tujuan pembelajaran yang hendak dicapai dan menjelaskan kebermaknaan tugas bagi peserta didik.

2) Menjelaskan topic yang menjadi tugas peserta didik termasuk kesulitan yang mungkin timbul dan cara pemecahannya.

3) Mengimformasikan prosedur penyelesaian tugas, misal:

a. Tugas diselesaikan secara individu atau kelompok;

b. Teknik pelaporan tugas, seperti: pendahuluan, permasalahan, pemecahan masalah, kesimpulan dan saran;

c. Apabila peserta didik dalam menyelesaikan tugas menemui kesulitan sekalipun sudah diberikan penjelasan tentang cara mengatasinya, maka ia diberikan kesempatan untuk konsultasi, misal pada jam istirahat;

4) Menginformasikan batas waktu penyelesaian tugas.

C.Tahap Akhir atau Tindak Lanjut

1) Memeriksa laporan dengan memberikan ulasan seperlunya baik berupa pujian secara tertulis di atas laporan maupun ralat-ralat dan sebagainya;

2) Memberikan penilaian dan kesimpulan tentang pelaksanaan tugas;

3) Mengadakan diskusi klasikal tentang kesulitan yang tidak terpecahkan dalam penyelesiaian tugas. (Aboe Dharie, 1994, p.28-30)

Dari uraian diatas, maka dapat dikatakan keberhasilan proses belajar mengajar menggunakan lembar penugasan terutama dapat menyajikan pengalaman yang konkrit, mengaktifkan dan membangkitkan minat peserta didik, meningkatkan penyimpanan hasil belajar, mengembangkan proses berpikir dengan menyediakan aneka ragam cara berpikir, memanfaatkan waktu secara efektif, dan memberikan pengalaman tertentu yang tanpa lembar pengajaran tidak mungkin diperoleh secara mudah.

\section{Metode}

Rancangan Penelitian Tindakan Kelas yang peneliti uraikan berpatokan kepada apa yang dikemukakan oleh Suharsimi Arikunto, Suharsimi Arikunto membuat empat tahapan Penelitian Tindakan Kelas, yaitu (1) perencanaan, (2) pelaksanaan,(3) pengamatan, (4) refleksi. Penelitian tindakan kelas ini tindakan yang dilakukan adalah sebagai berikut yaitu:

a. Waktu dilaksanakan setiap jam pelajaran geografi selama dua setengah bulan berturut-turut, yaitu: 
1. Siklus I pada bulan Juli 2014

2. Siklus II pada bulan Agustus 2014

3. Siklus III pada bulan September 2014

b. Tempat: Di kelas XII IPS 1 SMAN 1 Muaro Jambi Jambi

Subyek penelitian ini adalah siswa kelas XII IPS 1 Tahun Pelajaran 2013/2014 di SMAN 1 Muaro Jambi.Jumlah siswa 27 orang, yang terdiri dari 12 siswa laki-laki dan 15 siswa perempuan. Penelitian Tindakan Kelas ini dilaksanakan pada semester ganjil tahun pelajaran 2014/2015. Pekerjaan dan pendidikan orang tua siswa sangat beragam. Pekerjaan dan pendidikan orang tua siswa dapat dirinci berpendidikan sebagai berikut:

> Pendidikan Ayah: SMP 4 Orang, SLTA 11 orang, D1 1 orang, D3 1 orang dan S1 sejumlah 10 Orang

Pendidikan Ibu: SD 1 orang, SMP 6 orang, SLTA 12 orang, S1 8 orang.

$>$ Pekerjaan Ayah: PNS 10 orag, Pensiunan PNS 2 orang, Swasta 8 orang, Petani 1 orang, dan Pedagang 6 orang.

Pekerjaan Ibu: PNS 10 orang, Swasta 5 orang dan Rumah Tangga 12 orang. Untuk mengumpulkan data, terlebih dahulu di buatlah instrumen penelitian, yaitu instrument alat evaluasi hasil sebagai instrumen utama, yang merupakan bagian interval dalam Rencana Pelakasanaan Pembelajaran. Instrumen alat evaluasi belajar adalah bentuk tes objektif yaitu, jenis pilihan berganda dengan lima alternatif pilihan jawaban. Dalam analisis data peneliti mengumpulkan data dari hasil belajar siswa yaitu hasil tes formatif, apabila sudah diperoleh dalam bentuk skor mentah, maka skor mentah tersebut diolah lagi yang pada akhirnya menjadi nilai akhir siswa.

\section{Hasil}

Dalam penerapan setiap siklus kelihatan ada perbedaan kemampuan siswa antara siklus yang satu dengan siklus yang lainnya. Antara siklus satu dengan siklus dua dan siklus dua dengan siklus tiga tampaknya jauh sekali perbedaannya, oleh sebab itu dapat disimpulkan bahwa kemampuan siswa dengan adanya pemberian tugas dan kertas tugasnya dikembalikan dengan sendirinya kemampuan siswa pada siklus ketiga meningkat dibandingkan siklus satu dan dua.

Setelah diamati lebih jauh kemampuan siswa memahami dan mengerjakan tugas pada waktu pra tindakan selama dua jam pelajaran diadakan kuis (tes) nilai yang diperoleh siswa rata-rata adalah 65,17 dengan persentase ketuntasan 27,59 $\%$ dari 27 siswa,ini dilakukan pada siklus pertama. Sesudah dijelaskan dan penjelasan itu dilengkapi dengan contoh-contoh dan pemberian tugas, maka pada siklus kedua diadakan kuis terdapat peningkatan nilai siswa menjadi naik, yaitu menjadi 68,97 dengan persentase ketuntasan 72,41 \% dari 27 siswa namun masih dibawah stadar ketuntasan minimal (80), pada siklus tiga setelah diadakan tindakan dengan pengamatan dan pemberian tugas, maka nilai rata-rata siswa meningkat menjadi 81,38 dengan persentase ketuntasan 82,76\% dari 29 siswa.

Pada siklus ketiga setelah diadakan pemberian tugas dan dijelaskan cara mengerjakannya terhadap masing-masing siswa, maka nilai siswa menjadi meningkat dengan prestasi baik yaitu, untuk lebih jelasnya lihat tabel berikut : 


\begin{tabular}{|c|l|c|c|}
\hline No & Pelaksananan & $\begin{array}{c}\text { Nilai } \\
\text { Rata-rata }\end{array}$ & \% Ketuntasan \\
\hline 1 & Siklus 1 & 65,19 & 27,56 \\
\hline 2 & Siklus 2 & 67,97 & 72,41 \\
\hline 3 & Siklus 3 & 82,07 & 86,21 \\
\hline
\end{tabular}

Tabel : Nilai Rata-rata Hasil Tes akhir Tiap Siklus

\section{Siklus I}

\section{Hasil Tindakan pada Siklus I}

Pada pelaksanaan siklus I ini tindakan yang dilakukan adalah menyiapkan hal-hal yang berkaitan dengan perlengkapan mengajar. Menindak lajuti tindakan dalam penyajian pembuatan tugas tentang konsep dasar, tindakan yang dilakukan dengan cara menjelaskann, tanya-jawab dan memberikan beberapa contoh fenomena geosfer dalm kehidupan sehari-hari.

\section{Pengamatan Siklus I}

Pengamatan pada siklus I ini membuahkan hasil, yaitu siswa sudah semakin mengerti dan sudah mulai memahami penjelasan guru dengan baik tentang materi yang dipelajari dan memberikan latihan-latihan. Dengan demikian siswa sudah mulai mampu membadakan antara unsur-unsur pembuatan peta. Pada pengamatan lebih lanjut ditemui, bahwa siswa di dalam membuat mengejakan tugas dengan santai dan senang, sebab mereka membuatnya dengan bekal pengertian, maksudnya mereka sudah mengerti, dan memahami apa yang akan mereka buat dan bagaimana cara menyelesaikannya.

Sebelum siswa dibekali ilmu untuk mengerjakan tugas, siswa kelihatan kurang bergairah untuk mengerjakan tugasnya, hal ini disebabkan mereka belum mngerti tentang bentuk dan cara menjawab dan menyelesaikannya.

Setelah siswa dibekali dengan ilmu dan cara mengerjakan tugas serta menjawabnya, siswa mulai semakin aktif menjawab tugas-tugas atau pertanyaan dan mereka bisa membedakan unsusr-unsur pembuatan peta dan dapat menghitung skala peta. Apa yang dibuat siswa tersebut dapat dilihat pada siklus I ini dan nilai siswa rata-rata adalah 65,19 . Jadi pemberian tugas pada siklus I ini masih belum sempurna, namun apa yang ditulis siswa ini sudah lebih meningkat sebelum mereka diberi pamahaman tentang konponem pembuatan peta.

\section{Refleksi Tindakan Siklus I}

Peneliti mengadakan kegiatan refleksi setelah mengamati kegiatan siswa pada pelaksnaan kegiatan siklus pada siklus I ini yang diamati adalah hal-hal yang berkaitan dengan tanya jawab, yaitu antar siswa dengan peneliti dan juga latihanlatihan dengan memanfaatkan buku geografi dan LKS. Nilai yang diperoleh siswa pada siklus I ini rata-rata 65,19, yang dikategorikan nilainya kurang, namun demikian yang dicapai siswa pada siklus I ini tekah ada peningkatan dibandingkan dengan kegiatan yang dilaksanakan pada pratindakan, karena hasil yang diperoleh 
belum mencapai stndar yang telah ditentukan, peneliti merencanakan lagi untuk melanjutkan penelitian untuk siklus II. Setelah dipelajari dan diteliti lebih jauh lagi, maka untuk siklus ke II ini peneliti mengubah strategi, dan situasi yang akan dikerjakan oleh siswa.

\section{Siklus II}

\section{Hasil Tindakan pada Siklus II}

Pada siklus II ini yang dilaksanakan adalah mempersiapkan segala sesuatu untuk melakukan tindakan dalam membuat tugas mengenai pendekatan geografi dalam kedhidupan sehari-hari yang nyata. Disini pemberian tugas tidak sama dengan siklus I. Pada siklus II ini siswa langsung dihadapkan kepada kenyataan yang ada dalam ruang kelas yaitu untuk menghitung skala peta ruang kelas, maksudnya adalah siswa menghitung jumlah keramik lantai runag kelas dan digambarkan dengan menggunakan skala.

Setelah diamati lebih jauh, tampak hasil kerja siswa semakin meningkat, maka prestasi siswa atau nilai rata-rata siswa menjadi meningkat, dibandingkan dengan nilai rata-rata pada siklus I. Di samping itu siswa semakin paham tantang konsep dasar pembuatah peta.

\section{Pengamatan Siklus II}

Berdasarkan hasil pengamatan peneliti pada siklus II, yaitu telah terjadi paningkatan pemahaman dan kemampuan siswa, sehingga kelihatan dari hasil belajar maupun dari keaktipan siswa dalam proses belajar. Siswa semakin yakin dengan kemampuannya dan kemampuan siswa tersebut meningkat disebabkan mereka sudah semakin mengerti dengan apa yang akan mereka buat. Sehingga sebagian besar siswa sudah mampu mengerjakan tugas-tugas yang diberikan.

Akibat pemahaman siswa meningkat, maka kemampuan siswa juga meningkat, dengan demikian hasil yang diperoleh siswa menjadi meningkat. Kalau diperhatikan pada siklus I nilai rata-rata siswa 65, 19 sedangkan pada siklus II nilai rata-rata siswa mencapai 67,97 dengan kategori masih kurang karena nilai rata-rata siswa masih dibawah nilai kriterian ketintatasan minimal yaitu 80 .

\section{Refleksi Tindakan Siklus II}

Sesudah siklus II diamati, maka hasil pengamatan direfleksikan lagi pada siklus III, diharapkan pada siklus III ini hasilnya semakin lebih baik. Pada siklus III ini kegiatan mengarah pada pemahaman konsep pembuatan peta. Ternyata hasilnya jauh lebih baik dan memuaskan.nilai rata-rata siswa menjadi 82,07 dengan persentasi ketuntasan $86,21 \%$ dari 29 siswa.

Dengan demikian dapat direfleksikan bahwa hasil belajar siswa setiap siklus terus mengalami peningkatan, dan hasil belajar yang dicapai siswa terus meningkat dan mengalami perbaikan. Dengan demikian peneliti dapat disimpulan bahwa dengan adanya pemberian tugas dapat meningkatkan prestasi belajar siswa kelas XII IPS 1 SMA Negeri 1 Muaro Jambi Kabupaten Muaro Jambi.

\section{Pembahasan}

Peneliti mencoba membandingkan dan menganalisis pembelajaran dimulai dari awal, yaitu pada siklus I sampai pada siklus III di kelas XII IPS 1 SMAN 1 Muaro Jambi. Perbandingan dan penganalisisan didasarkan pada pemberian tugas dan pengembalian kertas tugas, ternyata apa yang sudah diberikan dan apa yang sudah dilaksanakan siswa memberikan hasil yang lebih baik. Keterampilan siswa 
mengerjakan tugas dan soal-soal dapat meningkat, hal ini ditandai dengan nilai rata-rata yang didapat siswa juga meningkat.

Berkenaan dengan tujuan penelitian ini, dengan adanya pengembalian kertas tugas siswa dari pelaksanaan siklus I dan siklus II terjadi peningkatan yang signifikan terhadap prestasi belajar siswa, terlihat dari hasil nilai tugas yang diberikan. Oleh karena itu dapat dikatakan bahwa dengan metode pemberian tugas, maka prestasi belajar siswa meningkat dan keterampilan siswa bertambah, serta tanggung jawab siswa semakin besar dan siswa bergairah mengerjakan tugas yang diberikan oleh guru.

\section{Kesimpulan}

Berdasarkan hasil penelitian yang dilakukan dan pembahasannya dapat disimpulkan bahwa penggunaan metode pemberian tugas dan hasil tugas siswa dikembalikan sesudah dikoreksi dalam proses pembalajaran geografi dapat meningkatkan prestasi belajar siswa. Hal ini ditandai dengan peningkatan nilai rata-rata siswa mulai dari siklus satu sampai siklus ketiga. Penggunaan metode ini juga dapat menumbuh kembangkan gairah belajar siswa.

\section{Saran}

Sehubungan dengan kesimpulan diatas maka, disarankan untuk mendapatkan hasil perolehan belajar yang baik pada mata pelajaran Geografi, hendaknya guru sejenis dapat menggunakan atau membiasakan diri dalam proses belajar mengajar dengan pemberian tugas kepada siswa dan kertas tugasnya setelah dinilai dikembalikan kepada siswa.

\section{Daftar Rujukan}

Adipurnomo, Haryono. 1994. Perangkat Pembelajaran. Malang: PPG IPS DAN PMP.

Dharie, Aboe. 1994. Metode Pembelajaran. Malang: PPG IPS DAN PMP. Dimyati, Mahmud. 1989. Psikologi Pendidikan. Jakarta: P2LPTK, 1989.

Purwanto, Nagalim. 1991. Psikologi. Bandung: Remaja Rosda Karya.

Rusyan, Tabrani. 1989. Pendekatan Dalam Proses Belajar Mengajar. Bandung: Remaja Rosda Karya.

Sardiman. 1994. Interaksi Dan Motivasi Belajar Mengajar. Jakarta: PT Raja Grafindo.

Winkel.W.S. 1991. Psikologi Pengajaran. Jakarta: PT Grasindo. 